Western North American Naturalist 67(3), (C) 2007, pp. 461-467

\title{
THE NEW MEXICO WHIPTAIL, CNEMIDOPHORUS NEOMEXICANUS (SQUAMATA: TEIIDAE), IN THE GREAT BASIN OF NORTH CENTRAL UTAH
}

\author{
George V. Oliver ${ }^{1}$ and John W. Wright ${ }^{2}$
}

\begin{abstract}
We report the discovery of established populations of Cnemidophorus neomexicanus in the Salt Lake City area. These are the 1st records of this species in Utah and in the Great Basin and are far from all other known populations of the species. We conclude that C. neomexicanus was introduced in the Salt Lake City area, perhaps within the last 30 years.
\end{abstract}

Key words: Cnemidophorus neomexicanus, whiptail, Utah, Great Basin.

A single species of whiptail, Cnemidophorus tigris Baird and Girard, 1852, the tiger (or western) whiptail, has previously been reported from the northern Great Basin of western North America and from northern Utah. The presence of a 2nd species in this area was revealed when a captive whiptail from an urban area near Salt Lake City, which had been submitted to the Utah Division of Wildlife Resources in August 2002, came to our attention in July 2003. We examined this individual and determined that it was Cnemidophorus neomexicanus Lowe and Zweifel, 1952, the New Mexico whiptail, which is a unisexual (parthenogenetic) species. Subsequently, we conducted field investigations in the Salt Lake City metropolitan area in 2003 and 2004 and found that this species has established populations in this urban area on the eastern edge of the Great Basin in northern Utah.

For the purposes of this report, we employ the name Cnemidophorus neomexicanus. There had long been confusion and disagreement concerning the appropriate specific name for this lizard (Wright 1969), but this dispute was resolved by Opinion 1929 of the International Commission on Zoological Nomenclature (1999), which placed the name Cnemidophorus neomexicanus on the Official List of Specific Names in Zoology. Also, we note that Reeder et al. (2002) have proposed restricting Cnemidophorus Wagler, 1830, to certain neotropical species and referred all species that naturally occur north of Guatemala and Honduras to the resurrected name Aspidoscelis Fitzinger, 1843. Under their proposed arrangement, Cnemidophorus neomexicanus would be Aspidoscelis neomexicana (Lowe and Zweifel, 1952). Although many recent authors have followed this arrangement, others have not (e.g., Taylor 2002, Stebbins 2003, Axtell 2003, Persons 2005).

In addition to the captive individual, which was from Lehi, Utah County, we found $C$. neomexicanus at 2 other locations, both in Salt Lake County: the northernmost part of Salt Lake City, a short distance south of the boundary with the suburb of North Salt Lake and Davis County; and Sandy City, a suburb south of Salt Lake City. Two adults from the Salt Lake City locality have been preserved as voucher specimens and deposited in the herpetological collection of Brigham Young University (BYU 48258, 48259); another adult from this locality is shown in Figure 1 (see Appendix for exact locations and other data).

These localities form a nearly straight northsouth line $\sim 45 \mathrm{~km}$ long, with the Sandy City locality being approximately midway between the Lehi and Salt Lake City localities. All 3 sites are within the Salt Lake City metropolitan area, the urban and suburban landscape that surrounds and connects them being almost entirely developed for residential, commercial, and industrial purposes.

The Lehi locality is a yard in a residential neighborhood. This locality is $\sim 125 \mathrm{~m}$ from the near edge of the pavement of Interstate Highway 15, and in addition to houses and

${ }^{1}$ Utah Natural Heritage Program, Utah Division of Wildlife Resources, 1594 West North Temple, Salt Lake City, UT 84116. E-mail: georgeoliver@utah.gov ${ }^{2}$ Curator Emeritus, Natural History Museum, Los Angeles, CA 90007. 


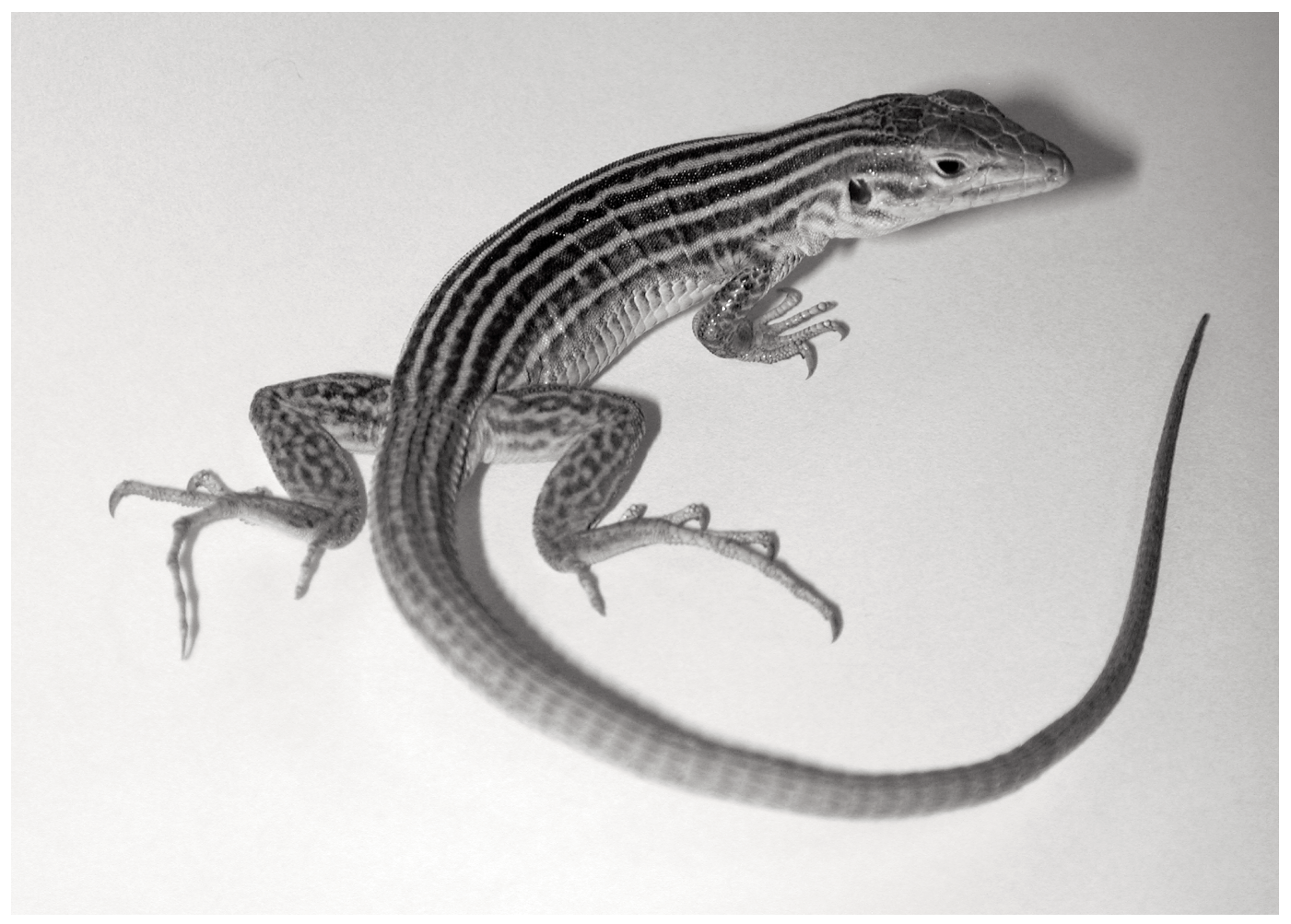

Fig. 1. Cnemidophorus neomexicanus from Salt Lake City, Salt Lake County, Utah, captured 13 August 2004, snout-vent length $69 \mathrm{~mm}$. Several characters diagnostic of the species (Wright and Lowe 1967, Wright 1971) are illustrated: the vertebral (or middorsal) stripe is wavy and bifurcates at the occiput, and the circumorbital (or supraorbital) scales extend far forward.

businesses, there are 3 schools, 3 parks, a cemetery, and a gravel pit in the vicinity. Both of the other sites where we found C. neomexicanus also are disturbed, especially the Salt Lake City locality, which is along a road cut at the base of a steep hill and adjacent to a gravel quarry. Dumping of trash has occurred at this locality, and in the immediate vicinity there are other gravel quarries as well as oil refineries, railroad yards, businesses, homes, streets, highways, and a park. The Sandy City locality, a suburban park, immediately adjoins a residential neighborhood. As with the Salt Lake City locality, a steep slope is present, the eroded bank of a deep ravine where bales of hay have been used to control erosion. At both of these latter locations, especially the Salt Lake City site, vegetative cover is sparse and ruderal, and at least $12(52 \%)$ of the combined 23 plant species that we observed at these sites are not native to North America (Appendix).

Cnemidophorus neomexicanus is well known to inhabit urban situations within its natural range (Wright and Lowe 1968), for example in El Paso, Texas (Cordes et al. 1989), and Albuquerque, New Mexico (Christiansen et al. 1971). In the urban area where they studied this species, Christiansen et al. (1971) found that $C$. neomexicanus prefers areas disturbed by human activities, and their observations agree well with ours in the Salt Lake City area. That C. neomexicanus is successful in disturbed urban settings is consistent with its usage of natural habitats, which, in addition to desert grasslands, include riparian corridors perpetually disturbed by floods (Wright 1971). Reviewing the biology of $C$. neomexicanus, Wright (1971) noted that "the activities of man and his animals in disturbing habitats appears to favor expansion of the range of the species."

Salt Lake City is far removed-to the north and to the west-from all other known populations of C. neomexicanus (Fig. 2). This species occurs mainly in the Rio Grande Valley from north central New Mexico to extreme western Texas (El Paso), west of the Rio Grande to 


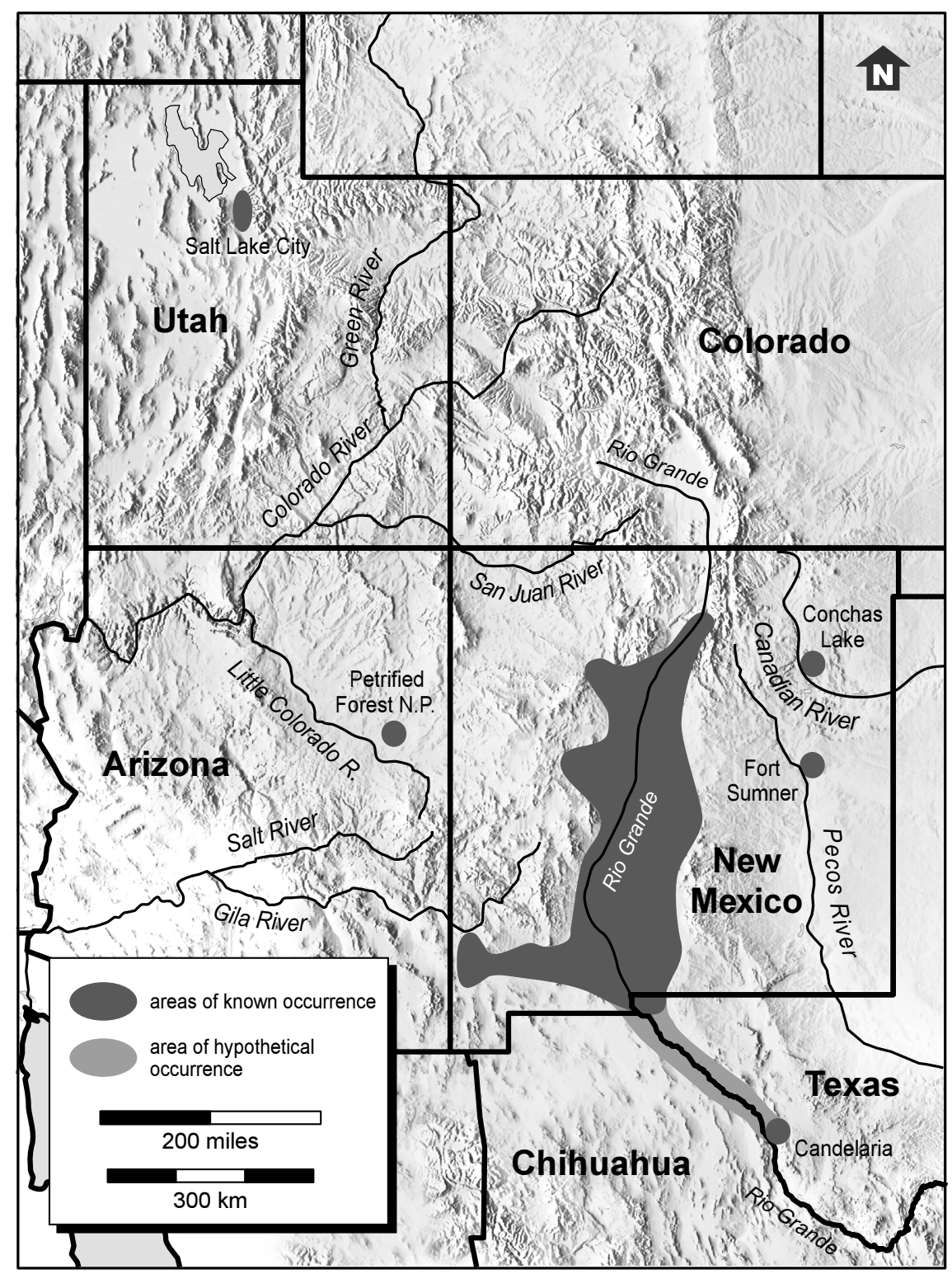

Fig. 2. General distribution of Cnemidophorus neomexicanus showing the newly discovered occurrence in the Salt Lake City area, Utah, relative to occurrences in Arizona, New Mexico, and Texas (adapted from Axtell 1966, Wright 1971, Cole et al. 1988, Degenhardt et al. 1999, and Persons and Wright 1999). The species has not been detected on either side of the Rio Grande within the area indicated as hypothetical (see text).

Lordsburg near the Arizona border in southwestern New Mexico (Pough 1961), and southeast along the Rio Grande to Candelaria, Texas (Cordes et al. 1989), and presumably in extreme northern Chihuahua (Axtell 1966, Wright 1971), although continuous distribution between El Paso and Candelaria has not been verified, and efforts to find this species in Chihuahua have thus far been unsuccessful (J.M. Walker, personal communication, 2006).

Additionally, there are 3 populations that are considered widely disjunct from the main range of the species and that we believe have resulted from human introductions, notwithstanding the differing conclusions of others regarding 2 of the populations. One of these is 
in northeastern New Mexico at Conchas Lake, San Miguel County, $\sim 190 \mathrm{~km}$ east of the nearest reported locality in the Rio Grande Valley (Lueck et al. 1981). Walker et al. (1992), however, argued that this population may be the product of natural dispersal rather than artificial introduction and implied that it may not be disjunct. Another of these disjunct populations in New Mexico was recently discovered in Fort Sumner, De Baca County, $100 \mathrm{~km}$ south of Conchas Lake, and Taylor (2002) likewise considered it to be probably a natural occurrence. Manning et al. (2005) provided a detailed discussion of the opposing hypotheses concerning the origins of these 2 populations and noted that even they (namely, Manning, Cole, Dessauer, and Walker) were not in agreement concerning the question of whether these populations are natural or introduced. The 3rd disjunct and presumably introduced population is in eastern Arizona in Petrified Forest National Park, Apache County, 240 $\mathrm{km}$ west of the nearest known locality in the Rio Grande Valley (Persons and Wright 1999). Persons and Wright (1999) persuasively argued that this population is the result of human introduction.

The occurrence of $C$. neomexicanus that is closest to Salt Lake City is the introduced population in Petrified Forest National Park, Apache County, Arizona (Persons and Wright 1999), $\sim 628 \mathrm{~km}$ south-southeast of the Lehi site, the southernmost of the Utah localities reported here. The nearest occurrence of $C$. neomexicanus that is considered natural is " 2.5 mi. $\mathrm{W}$ and $4.5 \mathrm{mi} \mathrm{N}$ Chamita, along Rio Ojo Caliente," Rio Arriba County, New Mexico (Wright 1971), $\sim 685 \mathrm{~km}$ southeast of the Lehi locality.

Several formidable barriers to natural dispersal of C. neomexicanus isolate the Salt Lake City population from all other known populations. A chain of mountain ranges runs northsouth through Utah, separating the lower elevation habitats of the Great Basin (to the west and north) from those of the Colorado Plateau (to the east and south). In most of this mountainous region, habitats are characteristic of higher elevations and are unsuitable for Cnemidophorus (Wright and Lowe 1968) and particularly for C. neomexicanus, although some of the valleys may be somewhat less inhospitable to this species.
The Colorado River drainage and its deep gorges also separate Salt Lake City from all other populations of C. neomexicanus. Even though C. neomexicanus commonly inhabits riparian zones (e.g., Wright 1971) and C. tigris occurs on both sides of the Colorado River, this large river and its gorges could present an important obstacle to dispersal, especially for a species as young as $C$. neomexicanus, which, unlike bisexual species such as C. tigris, is believed to be of very recent origin (Brown and Wright 1979, Densmore et al. 1989)—like other parthenogenetic species of Cnemidophorus, perhaps as recent as 200-1000 years ago (Parker and Selander 1976, Wright 1993, Price et al. 1993). The continental divide further separates Utah from all other northern populations of $C$. neomexicanus except the introduced population in eastern Arizona. That C. neomexicanus could have surmounted these barriers and reached Salt Lake City through natural dispersal during the relatively short time that it is thought to have existed, without leaving intervening populations in the nearly $700-\mathrm{km}$ hiatus between north central New Mexico and north central Utah, is implausible.

The population of $C$. neomexicanus in the Salt Lake City metropolitan area is the northernmost and westernmost occurrence of this species and is its only known occurrence in Utah and in the Great Basin. We conclude that $C$. neomexicanus was introduced to the Salt Lake City metropolitan area through human agency. Because the species is parthenogenetic, a single individual-or even a single viable egg (e.g., transported with a potted plant) - would be sufficient to found a new population.

Introduction of C. neomexicanus in northern Utah may have taken place within the last 30 years, for W.W. Tanner of Brigham Young University in Provo, only $\sim 19 \mathrm{~km}$ from Lehi, did not include it in a comprehensive herpetological checklist for Utah (Tanner 1975), nor did he include any name that might have been a synonym of this species in an earlier checklist for Utah County (Tanner 1939). Similarly, earlier comprehensive lists of Utah reptiles (e.g., Van Denburgh and Slevin 1915), including several by authors residing in Provo and Salt Lake City (e.g., Tanner 1927, 1928, 1929, 1935, Woodbury 1931), did not include this species (i.e., earlier synonyms). However, occurrence of C. neomexicanus at locations $45 \mathrm{~km}$ 
apart in the Salt Lake City metropolitan area suggests that it has been in this area for some time. During the 1970s, captive colonies of several species of Cnemidophorus, including C. neomexicanus, were maintained at the University of Utah in Salt Lake City (e.g., Cuellar and McKinney 1976, Cuellar 1977). The University of Utah is $5 \mathrm{~km}$ southeast of the Salt Lake City locality reported here and at similar elevation. It is possible that these captive colonies were the source of the Salt Lake City populations of $C$. neomexicanus.

Introductions of animals have become increasingly frequent as human mobility has increased, especially during the last 600 years. In North America many reptiles, especially lizards, have been introduced from other continents, and there have also been many introductions of reptiles within North America to areas beyond their natural ranges. These include both the introduction of $C$. neomexicanus at Petrified Forest National Monument (Persons and Wright 1999, discussed above) and the introduction of another parthenogenetic whiptail, C. velox, at The Cove Palisades State Park, Jefferson County, Oregon, where it has become well established (Nussbaum et al. 1983, Stuart 1998, Stebbins 2003) far from its natural range on the Colorado Plateau.

It would be of interest to observe the effects of the introduction of $C$. neomexicanus on native lizards in the Salt Lake City area. Cnemidophorus tigris occurs in some if not all of the areas where we have detected C. neomexicanus. It has been suggested that parthenogenetic whiptails have the competitive advantage where they co-occur with their bisexual congeners (e.g., Cuellar 1993), but the ecological consequences of such coexistence are not well understood and deserve further study. The detection of introduced C. neomexicanus in the Salt Lake City area reported here could provide the basis for future studies on the ecological interactions of $C$. neomexicanus and native species in this area.

We thank Mike Canning for his encouragement of this work, assistance in the field, and review of the manuscript; Krissy Wilson for providing details concerning the Lehi lizard; James Dix for assistance in the field; M.A. "Ben" Franklin and Robert Fitts for plant identifications; and Cory Maylett for preparation of the map (Fig. 2). We thank Steven D. Aird, an anonymous reviewer, and especially James M. Walker, who reviewed the work in various drafts, for their comments, which improved the manuscript. This work was supported by the Utah Reclamation, Mitigation, and Conservation Commission (Cooperative Agreement 7FC-UT-00270), under provisions of the Central Utah Project Completion Act.

\section{Literature Cited}

AXTELL, R.W. 1966. Geographic distribution of the unisexual whiptail Cnemidophorus neomexicanus (Sauria: Teiidae)—present and past. Herpetologica 22:241253.

. 2003. Cnemidophorus (Aspidoscelis) exsanguis Lowe. Interpretive Atlas of Texas Lizards 28:1-10 + map 15.

Brown, W.M., AND J.W. Wright. 1979. Mitochondrial DNA analyses and the origin and relative age of parthenogenetic lizards (genus Cnemidophorus). Science 203:1247-1249.

Christiansen, J.L., W.G. Degenhardt, and J.E. White. 1971. Habitat preferences of Cnemidophorus inornatus and C. neomexicanus with reference to conditions contributing to their hybridization. Copeia 1971: $357-359$.

Cole, C.J., H.C. Dessauer, and G.F. Barrowclough. 1988. Hybrid origin of a unisexual whiptail lizard, Cnemidophorus neomexicanus, in western North America: new evidence and a review. American Museum Novitates 2905:1-38.

Cordes, J.E., J.M. Walker, J.F. Scudday, and R.M. AвUнteba. 1989. Distribution and habitat of the parthenogenetic whiptail lizard, Cnemidophorus neomexicanus (Sauria: Teiidae), in Texas. Texas Journal of Science 41:425-428.

Cuellar, O. 1977. Genetic homogeneity and speciation in the parthenogenetic lizards Cnemidophorus velox and C. neomexicanus: evidence from intraspecific histocompatibility. Evolution 31:24-31.

1993. Further observations on competition and natural history of coexisting parthenogenetic and bisexual whiptail lizards. Pages $345-370$ in J.W. Wright and L.J. Vitt, editors, Biology of whiptail lizards (genus Cnemidophorus). Oklahoma Museum of Natural History, Norman.

Cuellar, O., and C.O. McKinney. 1976. Natural hybridization between parthenogenetic and bisexual lizards: detection of uniparental source by skin grafting. Journal of Experimental Zoology 196:341-350.

Degenhardt, W.G., C.W. Painter, and A.H. Price. 1999. Amphibians and reptiles of New Mexico. University of New Mexico Press, Albuquerque. xvii + 431 pp.

Densmore, L.D., III, J.W. Wright, and W.M. Brown. 1989. Mitochondrial-DNA analyses and the origin and relative age of parthenogenetic lizards (genus Cnemidophorus). II. C. neomexicanus and the C. tesselatus complex. Evolution 43:943-957.

International Commission on ZoOlOGiCAL NomenclaTURE. 1999. Opinion 1929[:] Cnemidophorus neomexicanus Lowe \& Zweifel, 1952 (Reptilia, Squamata): specific name conserved. Bulletin of Zoological Nomenclature 56:162-163. 
Lueck, B.E., E.E. Lueck, II, AND R.T.B. Sherwood. 1981. A new population of New Mexico whiptail lizards, Cnemidophorus neomexicanus (Teiidae). Southwestern Naturalist 26:72-74.

Manning, G.J., C.C. Cole, H.C. Dessauer, and J.M. WALKER. 2005. Hybridization between parthenogenetic lizards (Aspidoscelis neomexicana) and gonochoristic lizards (Aspidoscelis sexlineata viridis) in New Mexico: ecological, morphological, cytological, and molecular context. American Museum Novitates 3492:1-56.

Nussbaum, R.A., E.D. Brodie, Jr., and R.M. Storm. 1983. Amphibians and reptiles of the Pacific Northwest. University of Idaho Press, Moscow.

Parker, E.D., JR., and R.K. Selander. 1976. The organization of genetic diversity in the parthenogenetic lizard Cnemidophorus tesselatus. Genetics 84:791-805.

Persons, T.B. 2005. Distribution and habitat association of the little striped whiptail (Cnemidophorus inornatus) at Wupatki National Monument, Arizona. Report OF 2005-1139, U.S. Geological Survey, Southwest Biological Science Center, Flagstaff, AZ. 83 pp.

Persons, T., AND J.W. Wright. 1999. Discovery of Cnemidophorus neomexicanus in Arizona. Herpetological Review 30:207-209.

Pough, F.H. 1961. Range extension of the New Mexico whiptail lizard, Cnemidophorus perplexus. Herpetologica 17:270.

Price, A.H., J.L. LaPointe, and J.W. Atmar. 1993. The ecology and evolutionary implications of competition and parthenogenesis in Cnemidophorus. Pages 371-410 in J.W. Wright and L.J. Vitt, editors, Biology of whiptail lizards (genus Cnemidophorus). Oklahoma Museum of Natural History, Norman.

Reeder, T.W., C.J. Cole, and H.C. Dessauer. 2002. Phylogenetic relationships of whiptail lizards of the genus Cnemidophorus (Squamata: Teiidae): a test of monophyly, reevaluation of karyotypic evolution, and review of hybrid origins. American Museum Novitates 3365:1-61.

Stebbins, R.C. 2003. A field guide to western reptiles and amphibians. 3rd edition. Houghton Mifflin Company, Boston, MA. xvi + 533 pp.

Stuart, J.N. 1998. Cnemidophorus velox. Catalogue of American Amphibians and Reptiles 656:1-6.

Tanner, V.M. 1927. Distributional list of the amphibians and reptiles of Utah. Copeia 1927:54-58.

. 1928. Distributional list of the amphibians and reptiles of Utah[,] no. 2. Copeia 1928:523-528.
1929. Distributional list of the amphibians and reptiles of Utah[,] no. 3. Copeia 1929:46-52.

1935. Western worm-snake, Siagonodon humilis (Baird and Girard) found in Utah. Proceedings of the Utah Academy of Sciences, Arts and Letters 12: 267-270.

Tanner, W.W. 1939. Reptiles of Utah County. Proceedings of the Utah Academy of Sciences, Arts and Letters 16:105.

1975. 1975 checklist of Utah amphibians and reptiles. Proceedings of the Utah Academy of Sciences, Arts and Letters 52:4-8.

TAYLOR, H.L. 2002. Cnemidophorus neomexicanus (= Aspidoscelis neomexicana). Herpetological Review 33: 223-224.

Van Denburgh, J., and J.R. Slevin. 1915. A list of the amphibians and reptiles of Utah, with notes on the species in the collection of the Academy. Proceedings of the California Academy of Sciences, 4th series, 5:99-110 + 3 plates.

Walker, J.M., SR., J.E. Cordes, and J.M. Walker, Jr. 1992. Habitat preferences of a disjunct population of parthenogenetic Cnemidophorus neomexicanus (Sauria: Teiidae) in San Miguel Co., New Mexico. Southwestern Naturalist 37:82-97.

Woodbury, A.M. 1931. A descriptive catalog of the reptiles of Utah. Bulletin of the University of Utah 21(5) [Biological Series 1(4)]. xii + 129 pp.

Wright, J.W. 1969. Status of the name Cnemidophorus perplexus Baird and Girard (Teiidae). Herpetologica 25:67-69.

1971. Cnemidophorus neomexicanus. Catalogue of American Amphibians and Reptiles 109:1-3.

1993. Evolution of the lizards of the genus Cnemidophorus. Pages 27-81 in J.W. Wright and L.J. Vitt, editors, Biology of whiptail lizards (genus Cnemidophorus). Oklahoma Museum of Natural History, Norman.

Wright, J.W., AND C.H. Lowe. 1967. Hybridization in nature between parthenogenetic and bisexual species of whiptail lizards (genus Cnemidophorus). American Museum Novitates 2286:1-36.

1968. Weeds, polyploids, parthenogenesis, and the geographical and ecological distribution of allfemale species of Cnemidophorus. Copeia 1968:128138.

Received 13 June 2006 Accepted 2 February 2007 
APPENDIX. Localities for Cnemidophorus neomexicanus in north central Utah.

(1) Utah, Utah County, Lehi, North 200 East Street between East 900 North and East 1000 North streets; elevation $1400 \mathrm{~m} ; 40^{\circ} 24^{\prime} 2^{\prime \prime} \mathrm{N}$ latitude, $111^{\circ} 50^{\prime} 46^{\prime \prime} \mathrm{W}$ longitude. One very large adult (snout-vent length $74 \mathrm{~mm}$, total length $278 \mathrm{~mm}$, when examined after nearly a year in captivity) was submitted to the Utah Division of Wildlife Resources on 6 August 2002 by a homeowner who found it 1-2 days earlier in his residential yard. This locality is between the Stansbury and Provo shorelines of Pleistocene Lake Bonneville, and there is no appreciable slope.

(2) Utah, Salt Lake County, Salt Lake City, Victory Road (= Utah Highway 184) southeast of the intersection with 300 West (= U.S. Highway 89), near mouth of Hell Canyon; elevation $1433 \mathrm{~m}$; $40^{\circ} 47^{\prime} 27^{\prime \prime} \mathrm{N}$ latitude, $111^{\circ} 53^{\prime} 52^{\prime \prime} \mathrm{W}$ longitude. At this locality 1 neonate (snout-vent length 36 $\mathrm{mm}$, total length $111 \mathrm{~mm}$ ) was captured and at least 4 adults were observed on 31 July 2003. Several adults were also observed on 6 August and on 27 August 2003. Two adults (both with snout-vent length $69 \mathrm{~mm}$ ) were captured on 13 August 2004, and another adult (snout-vent length $69 \mathrm{~mm}$ ) was captured on 16 August 2004. One of the adults captured on 13 August 2004 and the adult taken on 16 August 2004 were preserved as voucher specimens (BYU 48258, 48259); the other adult captured on 13 August
2004 is illustrated in Figure 1. Plants observed at this site were mainly Chrysothamnus nauseosus, Bromus tectorum, Ambrosia acanthicarpa, Gutierrezia sarothrae, Grindelia squarrosa, Artemisia ludoviciana, Euphorbia myrsinites, Ulmus pumila, Gleditsia triacanthos, Celtis reticulata, Medicago sativa, Elaeagnus angustifolia, Salix exigua, Melilotus alba, Machaeranthera cf. canescens, Helianthus annuus, and a few Morus alba. The site is between the Stansbury and Provo shorelines of Pleistocene Lake Bonneville. Susbtrata are mainly gravel, and steep slopes $\left(\sim 30^{\circ}-45^{\circ}\right)$ are present.

(3) Utah, Salt Lake County, Sandy City, Dimple Dell Park, slope below Wrangler Trailhead and above Dry Creek; elevation $1529 \mathrm{~m} ; 40^{\circ} 33^{\prime} 44^{\prime \prime} \mathrm{N}$ latitude, $111^{\circ} 51^{\prime} 4^{\prime \prime} \mathrm{W}$ longitude. One neonate was captured, but escaped, on 6 August 2003. Prominent observed plants were Rhus aromatica, Elymus sp., Alyssum alyssoides, Bromus tectorum, Salsola tragus, Ambrosia acanthicarpa, Chrysothamnus nauseosus, Artemisia tridentata, Melilotus officinalis, Gleditsia triacanthos, and Grindelia squarrosa. This locality is between the Provo and Bonneville shorelines of ancient Lake Bonneville. Substrata are mainly gravel, and steep slopes $\left(\sim 30^{\circ}-45^{\circ}\right)$ are present. 